\title{
Cambodian fashion NGOS: are they doing good?
}

\begin{abstract}
During the Khmer Rouge's genocide in the 1970s, Cambodia's entire infrastructure was destroyed and its ancient textile traditions were nearly eradicated. However, recently Cambodia has emerged as a top garment producer and also made great strides in restoring its world-famous sericulture. Fashion items are produced in large factories, in nongovernmental (NGO) organizations/associations and in private enterprises. While large-scale fashion production is Cambodia's biggest export industry, the industry is suffering from ongoing labor strife, low wages and poor work conditions. Another key problem of the industry is that the designs and market for the fashions are exclusively Western. In contrast, NGOs/associations have been championing a progressive social agenda and positively impacted the local civil society. They also laid the foundation for an emerging local fashion scene. NGOs generally recruit their employees from the most disenfranchised segments of the population, such as formerly prostituted women, homeless children and underprivileged youths or unemployed rural people. NGOs help these employees get skills training and cultivate and harness their creativity. However, NGO fashion production also has its downside. These include financial instability, too much focus on donor priorities, massive bureaucracy, and lack of accountability to local workers by foreign donors and passive execution of Western design ideas. At the same time, there are positive examples as well. Successful fashion NGOs not only provide employment, but teach financial, management, design and entrepreneurial skills to their constituents as well. They also promote collective decision making, emphasize local aesthetics and utilize local physical and human resources.
\end{abstract}

Volume I Issue 4 - 2017

\author{
Katalin Medvedev \\ The University of Georgia, USA
}

Correspondence: Katalin Medvedev, The University of Georgia, USA, Tel 706542 4307, Email medvedev@uga.edu

Received: February 21, 2017 | Published: April 20, 2017

Keywords: cambodia, fashion, garment production, international labor laws, cambodian garment industry, nongovernmental organizations, civil society

\section{Introduction}

Fashion is one of the cornerstones of cultural and economic globalization. The 1974 Multi-Fiber Arrangement offered developing nations order quotas to enter the garment trade. This meant a somewhat fair shot for clothing producers in developing countries, while spreading the apparel industry worldwide. When the garment industry became international, national governments with scarce natural resources, like Cambodia, sought to provide the global garment industry with cheap labor. Access to cheap labor in Cambodia meant easy access to people in poverty, or more precisely, access to women in poverty. Women make up 90-92 percent of Cambodia's 700,000 strong garment industry work-forces. ${ }^{1}$ Cambodian garment workers are mostly young women who travel to Phnom Penh from rural provinces in search of work. These young women represent a steady supply for the garment industry-because in Cambodia it is a daughter's filial responsibility to contribute to the family finances. ${ }^{2}$

\section{Cambodian garment production}

Garment production is important for Cambodia because it has few natural resources. It has become the country's second largest industry after agriculture. ${ }^{3}$ The garment and footwear sector already accounted for roughly 80 percent of the country's total exports in 2014. In the first quarter of 2015, the sector exported goods worth $\$ 1.5$ billion, while the rate increased 7.9 percent. ${ }^{4}$ This is impressive if we consider that the major market for Cambodian-made garments is the European Union, which is in a recession. 42 percent of the total volume of garment exports goes to the EU, the rest primarily to Canada and the U.S. Garments are manufactured in nearly 600 factories, producing apparel for around 200 global brands. ${ }^{5}$ Although
Cambodian garment exports are huge, close to $\$ 6$ billion dollars a year, the profits are expatriated out of the country. This is because these garment and footwear factories are mostly owned by Chinese, Taiwanese, Malaysian or South Korean corporations. ${ }^{6}$ Problems arise because the existing factory owners are almost all male and do not understand their female workers' daily problems such as child and health care. Because of profit expatriation, foreign investors are not interested in upgrading or diversifying the 'cut, make, and trim' industry or training their employees in complex tasks. Updating production technology and infrastructure or raising labor standards are also not on their list. They simply import raw materials into the country, take advantage of cheap labor locally, and pocket the profits.

\section{Cambodian government and the garment industry}

The precarious situation of the Cambodian garment industry is not likely to change because the Cambodian government is the most corrupt in Southeast Asia, 150th out of 168 countries in the world. ${ }^{7}$ Government officials benefit from massive kickbacks from foreign factory owners. In return, the factories are provided with police protection. Many of the Cambodian garment factories are prison-like facilities equipped with surveillance towers and barbed wire fences. They are generally located out of sight, in so-called 'Free Trade Zones' where the foreign garment producers are protected from liability and can suspend international labor laws and ignore human rights. ${ }^{8}$ Because garment production is so important for Cambodia's economy and for government officials, the government has not refrained from using police violence against striking garment workers to suppress their demands. Some confrontations have even resulted in fatalities. ${ }^{9}$ Other government measures against the local workforce include a series of laws to limit the freedom of expression and assembly of 
workers, while tightening the regulations of union registration and reporting requirements. ${ }^{10}$

\section{Work conditions in garment factories}

Despite government repression Cambodian garment workers have vigorously protested unacceptable work conditions. For example, because of the excessive heat in factories that often reaches 50 Celsius, news of mass fainting has been widely publicized. ${ }^{11}$ Workers fell ill also because in over 60 percent of the factories women did not have proper access to drinking water. ${ }^{8}$ Garment workers also complained about serious breathing problems at work. The dust, the lint and suspended toxic particles in the air, mixed with high humidity and lack of ventilation, makes working at garment factories akin to working in a coal mine. In Free Trade Zones there have also been issues with excessive overtime without compensation, improper emergency facilities and dangerous equipment. Ignoring fire regulations or storage of hazardous chemicals on the premises are also frequent. ${ }^{6}$

\section{Unionization of garment workers}

Because of extensive security and surveillance measures and fear of retribution, the majority of workers in Free Trade Zones are not unionized. This creates a two-tier system of unionization in the Cambodian garment sector, which is actually 55 percent unionized. In fact, the 55percent unionization level is much higher than in Bangladesh, Cambodia's competitor. This rate is likely related to socialist Vietnam's role in Cambodia's political history. However, the government allows several unions to operate in one workplace, which ends up weakening each, or management adds its own "yellow" company unions, which only pretend to represent workers' interests. ${ }^{12}$ On the flip side, because of the relatively high unionization rates, workers were able to demand raises and were partially successful. However their most recent attempts to raise the minimum wage were rejected by such retail giants as Walmart or brands like Nike. ${ }^{13}$ While The ILO Better Factories Cambodia organization found 97 percent compliance with the existing minimum wage laws, the actual minimum wage in 2012 was still only 19 percent of the actual living wage, so the law itself is deficient. It continues to amount to only 80 percent of the actual living costs because raises have been pegged to the inflation rate and not to actual living costs. ${ }^{14}$ Because of similar trends in the global garment trade, the garment industry became perhaps the most responsible party for generating a world-wide gender wage gap. Unfortunately, besides the garment sector, Cambodian women have practically only one other employment option-sex works. ${ }^{8}$ This means that employment in the garment industry is perhaps a lesser of two evils. Garment work is monotonous, back breaking and entrenches gender-based poverty. Despite this, garment work is still viewed as a coveted job because until very recently teachers could be paid even less. ${ }^{15}$ This under-appreciation of intellectual work is likely a legacy of the Khmer Rouge, which obliterated artistic expression and any form of urban intellectualism or skilled labor.

\section{NGO fashion production in cambodia}

Besides the government-backed garment sector, nongovernmental organizations (NGOs) also produce fashion products in Cambodia. Globalization in the South made NGOs quite powerful in terms of creating new policies and practices. They have become the darlings of the international development machine because they tend to work with the poor. ${ }^{16}$ In Cambodia they were expected to be tools of democratization, in the hope that the causes they champion will counter the activities of the corrupt government.
Institutionally, NGOs occupy a space between government, market, and civil society. They are supposed to have a long-term transformative and social justice agenda that benefits the local civil society. ${ }^{16}$ Cambodia, which suffered from a horrific blood-letting and civil war, has one of the largest numbers of NGOs in the world, close to $2000,{ }^{17}$ because the issues the post-conflict nation had to resolve were endless. That the NGO numbers continue to be high, decades after the slaughter, suggests that the population has lost faith in the post-Khmer Rouge political system.

Although NGOs often do the job of the government and, therefore, are welcome in most locations in the world, the repressive Cambodian government distrusts them because they are inherently political. The fact that they are mostly financed by foreign donors makes them even more suspicious and helps the government use the "too much foreign influence" ticket against them. If an NGO "violates the dignity and morality of the country" they are suspended, which allows the government to control civil society. ${ }^{18}$ The government keeps a close tab on the NGO sector because it is trying to make sure that NGOs are more invested in cultural and religious issues than structural or economic ones.

\section{Problems of NGO fashion production}

Another side of Cambodian NGOs is that they often do not ally with local needs. They are designed and controlled in a top-down manner dictated by donor priorities, which is antithetical to the core values of NGOs. ${ }^{16}$ For example, a disproportionally large number of Cambodian NGOs have been established by Western religious organizations. Although the foreign donors, often Christian charities, do champion a positive social agenda, they require their Buddhist constituents to reject their own religious roots and cultural values in exchange for financial and technical support. In other words, help is linked to moral and cultural agendas rather than economic or structural ones, which means that the foreign donors end up installing a new form of benevolent, faith-based neocolonialism.

To ensure that operations are run according to Western standards, foreign donors tend to install an educated staff to lead NGOs. While this might make sense, this leadership is often disconnected from their constituents' daily realities. They might not feel the need for accountability, and this contributes to the de-politicization of NGOs and erosion of participatory contributions by NGO members, which, theoretically, are at the core of NGO operations. An additional problem is that Cambodian NGOs often compete for the same resources. As a result they become competitors, which further divide the already fragile local civil society.

By following foreign donor priorities, most Cambodian fashionproducing NGOs fail to change workers' lives. They end up actually paying less than the garment factories, which inadvertently helps prop up foreign investors. In sum, the NGO-ization of the Cambodian garment sector tends to undermine local interests and is complicit with state and foreign donor interests. This begs the question: How long will Cambodian women choose the same backbreaking jobs offered by NGOs that are run like ordinary factories, where concern for the agency and true well-being of the workers is not a priority? Do the perks generally offered by NGOs, such as free child care, limited medical care and educational opportunities and an abuse-free environment make them viable if they continue to keep workers in persistent poverty? Or is this just another form of exploitation?

Unfortunately, besides low wages, the success of garment- 
manufacturing NGOs is hindered by something else. Literature on NGOs suggests that innovation is central to NGO effectiveness. ${ }^{16}$ Yet, in Cambodia, most garment-producing NGOs create the same fashion products as other fashion NGOs elsewhere. This is because foreign donors rarely provide actual design education or care about local aesthetics. NGOs tend to be passive recipients of Western design ideas and keep reproducing prior ideas, such as totes made of fish feed bags or paper beads, which have flooded stores like Global Village in the U.S. This happens because the donors are often the same and so have the same agendas in Cambodia, Laos, Thailand, Myanmar, Vietnam or India. This practice prevents Cambodian NGOS from becoming competitive through originality. In addition, it leads to increased competition with other clothing and accessories-producing NGOs and ultimately weakens the entire civil sector in Asia. It also means that fashion products they produce are made, not for the local consumers, but for export or the benevolent cosmopolitan traveler. Here, however, we run into a dilemma. How do we negotiate the tension that exists between the needs of protecting traditional culture, destroyed by the Khmer Rouge and which is, therefore, on the brink of extinction today, with the needs of an increasingly modernized society where a large number of young people crave Western styles? ${ }^{19}$ Cambodian youth are now part of the international fashion scene. They do not have any experience of the Khmer Rouge. In fact, many sadly do not even know about the mass killings because their family members shelter them from the gravity of the national trauma suffered between the years of $1975-1979 .{ }^{20}$ This, however, means that they are not as invested in the conservation of traditional aesthetics as members of the older generation. An additional important problem is that the short-term deliverables required by donors are incompatible with innovation. True innovation is generally the result of a long process.

Many NGOs were established to pursue a genuine cause. Yet some do not survive because international donors support more bureaucratic NGOs over grassroots ones. ${ }^{16}$ The former have employees that master development jargon and follow the strict accountability and reporting requirements of Western donors, while grassroots NGOs do not have that capacity. Large NGOs are able to maintain an up-to-date web presence and thus promote their products to an international audience. The consequence of all this is that in the Cambodian NGO sector, bureaucratic and organizational aims end up trumping those of social transformation and economic empowerment.

\section{Fashion producing NGOs doing it right}

At the same time, there are also good civil society-initiated fashion practices in Cambodia, although they do not use the NGO label. Earlier I published three case studies of various Cambodian fashion-producing organizations that appear to do well and work for their constituents' wellbeing. ${ }^{21-23}$ For example, the Institute for Khmer Traditional Textiles has revived traditional textile traditions that were on the brink of extinction in Cambodia. It is now able to maintain an entire self-sustaining village in the Angkor Wat area. The downside of the operation is that it had to be launched by a foreigner, a former Japanese kimono silk dyer, Kikuo Morimoto. However, Morimoto dedicated his entire life to the project and continues to live in the village with his workers. ${ }^{23}$ Another example, the Stung Treng Women's Development Center, is successful in helping former sex workers move up the social ladder. They provide them with vocational skill training and health education, as well as entrepreneurial, management and accounting education. This allows these young women to seek job opportunities beyond the garment industry. ${ }^{22}$ Unfortunately, in the case of this Center there is also a downside; they did all this under the tutelage of a faith-based organization which advertises its goals with the following words: "We exist to bring freedom to the oppressed by demonstrating the love of Jesus Christ, preventing human trafficking and restoring communities". ${ }^{24}$ This suggests a moralistic agenda rather than an economic one, which is what people in Cambodia need most. Another example is the Rajana Association, which was established by a British Christian organization but has since reshaped itself into an independent organization. Their mission is to promote traditional Khmer crafts, using traditional methods and designs in their garments, but infuse them with modern design elements. In my field research, I have found this organization to be the most transparent and advanced in shaping the institutional environment and demonstrating accountability towards their members. However, Rajana also has a downside. Their store environments, the types of food in their coffee shops, all copy Western practices, which makes them somewhat devoid of a personality and contributes to the devaluation of Khmer culture.

\section{Conclusion}

Despite some issues, the three civil fashion-producing organizations, Rajana, the Stung Treng Women's Development Center and the Institute for Khmer Traditional Textiles, have been successful because they have invested in collaborative decisionmaking and prioritized local objectives versus donor objectives. They provide members with vocational training and help develop technical, financial, management, entrepreneurial and problem-solving skills. These in the long term help increase workers' labor prospects. Their projects articulate local realities and utilize local resources. While they have been successful in developing somewhat equal partnerships with their donor base, unfortunately, they have not been able to fully break their reliance on foreign donors. Despite this, they have made strides to raise the economic status of women and other marginalized groups, while successfully contributing to rural development. In sum, they have managed to combine local change with a higher level social and structural change.

\section{Acknowledgments}

None.

\section{Conflict of interest}

Author declares there is no conflict of interest in publishing the article.

\section{References}

1. "Work faster or get out": Labor rights issues in Cambodia's garment industry. Human Rights Watch. 2015.

2. Smith-Hefner NJ. Khmer American: Identity and moral education in a diasporic community. University Press, Oakland, California; 1999. p. $1-335$.

3. Cambodia Economy Profile. Index Mundi. 2016.

4. Cambodian Garment and Footwear Sector Bulletin, Issue 2: Solid first half of 2015 for Cambodia's garment and footwear sector. International Labour Organization. 2015.

5. We are fashion revolution Cambodia. Fashion Revolution.org.

6. Espinosa I. Prisons in Cambodia: The garment industry. Fashion Revolution.org. 2016. 
7. Parameswaran P. Cambodia now is ASEAN's most corrupt country. The Diplomat. 2016

8. Corman L, Jean D, Mendes M, et al. Threadbare: Clothes, sex \& trafficking. Microcosm Publishing, Portland, Oregon, USA; 2016.

9. Labour rights groups condemn violence against garment workers in Cambodia. Clean Clothes.org. 2014.

10. Davis J. NGOs squeezed: CCHR. Phnom Penh Post, Cambodia, Asia; 2016.

11. Hundreds of Cambodian garment workers faint. Aljazeera. 2014.

12. Kane G. Cambodia Fact Sheet February 2015. Clean Clothes Champion 2015.

13. Nelson S. Where are Gap, Walmart, H \& M and Zara on Cambodians minimum wage push? Jobs with Justice, USA; 2015.

14. Cambodia raises minimum wage for garment workers but unions remain unhappy. Radio Free Asia, USA; 2015.

15. Sokuntheapen. Low Teacher Salaries Harm Public Education in Cambodia. Education Policy talk. 2013.

16. Banks N, Hulme D, Edwards M. NGOs, states, and donors revisited: Still too close for comfort? World Development. 2015;66(C):707-718
17. CSO contribution to the development of Cambodia 2011. Cooperation Committee for Cambodia. 2012. p. 1-60

18. Carmichael R. Cambodia senate oks controversial NGO law. VOA. 2015 .

19. Kallio AA, Westerlund $\mathrm{H}$. The ethics of survival: Teaching the traditional arts to disadvantaged children in post-conflict Cambodia. International Journal of Music Education. 2016;34(1):90-103.

20. Moore AE. Cambodian grrrl: Self-publishing in Phnom Penh. Portland, Oregon: Microcosm Publishing; 2011.

21. Medvedev K. Designing from dumpsters: Cambodians start at grassroots with fashion. Fashion Practice. 2010;2(2):223-248.

22. Medvedev K, Reef B. Picking up the threads: Model approach helps Cambodia design and new fashion image. Women's Studies Quarterly. 2013;41(1/2):131-149.

23. Medvedev K. The roots of change in the contemporary Cambodian fashion scene. Inter J Fashion Studies. 2015;2(1):9-27.

24. We believe in a world where people never own the heartbreaking story of human trafficking. Freedom's Promise, Nashville, USA. 